\section{The Addition of Metamizole to Morphine and Paracetamol Improves Early Postoperative Analgesia and Patient Satisfaction after Lumbar Disc Surgery}

\section{Parasetamol ve Morfine Metamizol Eklenmesi, Lumbar Disk Cerrahisi Sonrası Erken Postoperatif Analjezi ve Hasta Memnuniyetini Artırır}

\begin{abstract}
AIM: Combined analgesic regimens produce sufficient analgesia by additive or synergistic effects, and reduce the total dose of analgesics and minimise adverse effects. We investigated the metamizole, paracetamol and morphine combination with respect to postoperative pain treatment in lumbar disc surgery.

MATERIAL and METHODS: After Ethics Committee approval and informed consent, 63 patients were allocated to three treatment groups; as Group paracetamol: paracetamol (1 g), Group paracetamol-metamizole: paracetamol (1 $\mathrm{g}$ ) and metamizole $(1 \mathrm{~g})$, and Group placebo: no analgesic. All the patients received intravenous (i.v.) morphine with a patient-controlled analgesia device (PCA) as the rescue analgesic. Pain was assessed by the numerical pain rating scale (NRS, 0-3). Total morphine consumption at 24 hours, patient satisfaction and side effects were investigated.

RESULTS: NRS of Group paracetamol-metamizole was low at 15th min, 30th min and 1st hour, and the difference reached statistical significance at 30th min $(p=0.033)$. Patient satisfaction at the same measurement times was high in this group. Total morphine consumption and side effects were not statistically different between the three groups.

CONCLUSION: Addition of metamizole to paracetamol along with iv morphine PCA offers an advantage over single iv morphine PCA and paracetamol, with respect to early postoperative pain treatment and patient satisfaction.

KEYWORDS: Non-narcotic analgesics, Paracetamol, Metamizole, Morphine, Lumbar disk surgery, Analgesics, non-narcotic
\end{abstract}

\section{ÖZ}

AMAÇ: Analjezik kombinasyonları, aditiv ve sinerjistik etkiler ile yeterli analjezi sağlarlar, ve total analjezik dozu ve yan etkilerde azalma olur. Biz çalışmamızda, metamizol, parasetamol ve morfin kombinasyonunun lumbar disk cerrahisi sonrası postoperatif ağrıya etkilerini araştırdık.

YÖNTEM ve GEREÇ: Etik komite izni ve aydınlatılmış onam formu alındıktan sonra, 63 hasta üç tedavi grubuna ayrıldı; Grup parasetamol: parasetamol (1 g), Grup parasetamol-metamizol: parasetamol (1 g), metamizol (1 g) ve Grup plasebo: hiçbir analjezik verilmedi. Bütün hastalara, ihtiyaç durumunda almak üzere, intravenöz morfin hasta kontrollü analjezi cihazı (HKA) bağlandı. Ağrı değerlendirmesi nümerik ağrı derecelendirme skalası (NRS, 0-3) ile yapıldı. 24 saatlik total morfin kullanımı, hasta memnuniyeti ve yan etkiler araştırıldı.

BULGULAR: Parasetamol-metamizol grubunun NRS değeri 15. Dak, 30. Dak ve 1. Saatte düşüktü, ancak 30. dak değeri istatistiksel olarak anlamlı farkliydi $(\mathrm{p}=0.033)$. Aynı ölçüm zamanlarına, hasta memnuniyeti bu grupta yüksek bulundu. Total morfin dozu ve yan etkiler açısından gruplar arası istatistiksel anlamlı fark yoktu.

SONUÇ: Parasetamol ve morfine, metamizol eklenmesi, tek morfin veya parasetamolden, erken postoperatif ağrı tedavisi ve hasta memnuniyeti açısından daha yararlıdır.

ANAHTAR SÖZCÜKLER: Narkotik olmayan analjezikler, Parasetamol, Metamizol, Morfin, Lumbar disk cerrahisi, Analjeziler:narkotik olmayan

\section{Sennur UZUN}

Illker ONGUC AYCAN

Ismail Aydin ERDEN

Altan SAHIN

Ulku AYPAR

Hacettepe University, Faculty of Medicine, Department of Anaesthesiology and Reanimation, Ankara, Turkey

Received : 18.03.2010

Accepted : 23.04.2010

Correspondence address:

\section{Sennur UZUN}

Hacettepe University, Faculty of Medicine,

Department of Anesthesiology and

Reanimation, Ankara, TURKEY

E-mail : sennuruzun@superonline.com 


\section{INTRADUCTION}

Systemic administrations of analgesics is the most widely used method to reduce postoperative pain after lumbar disc surgery. Opioids and nonsteroidal anti-inflammatory drugs (NSAIDs) play an important role in reducing postoperative pain (8). A combination of analgesics produces additive or synergistic effects and provides sufficient analgesia. Combined regimens can reduce the total dose of analgesics and minimize the adverse effects (4). The combination of opioid, NSAIDs and paracetamol reduces the postoperative opioid requirement and decreases the incidence of opioidinduced side effects (6). The paracetamol and NSAIDs combination is widely used clinically, but what this combination offers is still a matter of debate (19).

There are studies reporting that the addition of metamizole to morphine would potentiate morphine's antinociceptive effects $(2,9,14)$. However, the combination of metamizole (NSAID), paracetamol and morphine has not been evaluated previously with respect to postoperative pain control after lumbar disc surgery.

Previous studies have investigated a combination of paracetamol with intravenous (i.v.) morphine patient-controlled analgesia (PCA). There are conflicting results about this combination with respect to its opioid-sparing effect $(4,11,18)$.

The aim of this study was to investigate the effects of addition of i.v. metamizole to i.v. paracetamol along with i.v. morphine PCA in respect to total morphine consumption, pain alleviation and patient satisfaction after lumbar disc surgery.

\section{MATERIAL and METHODS}

After obtaining Ethics Committee approval and informed consent, 63 patients ASA I-II (American Society of Anesthesiologists), scheduled for singlelevel, unilateral lumbar disc surgery were informed about the use of the PCA device and the numeric pain rating scale (NRS). Patients with impairment in liver function, renal dysfunction, hypersensitivity or contraindication to the study drugs, or history of lumbar disc re-operations and the patients who would be operated on by residents were excluded. Only the operations of the senior experienced surgeons were included in the study.
Each patient was monitored in the operating room, to include electrocardiogram, noninvasive blood pressure measurements, and pulse oximeter use. Patients received a standard anesthetic regime. They were premedicated with $5 \mathrm{mg}$ diazepam orally, half an hour before the anesthesia induction. Anesthesia was induced with propofol $2.5 \mathrm{mg} \cdot \mathrm{kg}^{-1}$, fentanyl $1 \mu \mathrm{g} . \mathrm{kg}^{-1}$ and vecuronium $0.1 \mathrm{mg} . \mathrm{kg}^{-1}$ i.v. and maintained with $2 \%$ sevoflurane in $50 \% \mathrm{~N}_{2} \mathrm{O} / \mathrm{O}_{2}$. No fentanyl was administered in the last 30 minutes (min) of the surgery. At the end of the surgery, ondansetron $4 \mathrm{mg}$ was administered to minimize postoperative nausea and vomiting. Neostigmine $0.05 \mathrm{mg} \cdot \mathrm{kg}^{-1}$ and atropine $0.01 \mathrm{mg} \cdot \mathrm{kg}^{-1}$ were administered for reversal of neuromuscular blockade.

Patients were randomized to one of three treatment groups in a double-blind manner using a computerized allocation schedule and unlabeled syringes. After randomization, an anesthetist not involved in the patients care or data collection, prepared the unlabeled syringes and gave them to the anesthetist dealing with the patient care. In Group paracetamol-metamizole (Group PM), $1 \mathrm{~g}$ paracetamol (Perfalgan, $10 \mathrm{mg} \cdot \mathrm{ml}^{-1}$ ) was infused by a perfusor set to deliver $400 \mathrm{ml}^{\text {.hour }}{ }^{-1}$ over $15 \mathrm{~min}$ to enable double blindness at the end of the operation and i.v. $1 \mathrm{~g}$ metamizole (Adepiron, $500 \mathrm{mg} \cdot \mathrm{ml}^{-1}$ ) was injected during the skin closure. In Group paracetamol (Group P), paracetamol 1g was infused in the same manner as in the previous group and 2 $\mathrm{ml} 0.9 \% \mathrm{NaCl}$ i.v. was injected instead of metamizole. In Group placebo (Group C) no drug was administered. All the patients received morphine PCA as the rescue analgesic; loading dose $1 \mathrm{mg}$, bolus dose $1 \mathrm{mg}$, lock-out interval $10 \mathrm{~min}, 4$ hour (h) limit $20 \mathrm{mg}$, no background infusion. The device was connected immediately to all groups upon arrival at the postanesthesia care unit. The time elapsed from the end of surgery to the beginning of PCA was approximately $10-15 \mathrm{~min}$.

A blinded observer recorded pain, cumulative morphine consumption, adverse effects (nausea, vomiting, shivering, urinary retention) and patient satisfaction at postoperative 15 and $30 \mathrm{~min}, 1 \mathrm{~h}, 2 \mathrm{~h}$, $6 \mathrm{~h}$ and $24 \mathrm{~h}$.

Pain was evaluated by NRS as: 0: no pain, 1: mild pain, 2: moderate pain, and 3: severe pain. 
Patient satisfaction with postoperative pain management was assessed by a 4-point rating scale as: 0: poor, 1: moderate, 2: good, and 3: excellent.

\section{STATISTICAL ANALYSIS}

The SPSS 15.0 for Windows statistical package (SPSS Inc., Chicago, IL, USA) was used for all analyses. Patient characteristics, duration of the procedure, pain scores, postoperative morphine consumption, and morphine requests were analyzed using analysis of variance, Kruskal-Wallis test and $\mathrm{X}^{2}$-test, where appropriate. Normal distribution of numerical data was assessed using the Shapiro-Wilk test. Significance was determined at the $\mathrm{p}<0.05$ level. The Bonferroni approach was used for multiple comparisons. Results are given as medians (range) for non-parametric data and as mean \pm standard deviation (SD) for continuous data. The number of patients (approximately 20 patients per group) was assumed to detect (with $80 \%$ power and 5\% type- 1 error level) a 1-point difference in NRS scores (mean NRS score of 2 and assuming an SD of 1 in all groups) between the groups.

\section{RESULTS}

In total, the results of 63 patients were analyzed and no patient was excluded. Twenty patients were enrolled in Group C, 20 in Group P and 23 in Group PM. Patient characteristics, duration of surgery and anesthesia, and total intraoperative fentanyl use were similar among the groups (Table I).

We observed differences among the groups, with respect to NRS scores at $15 \mathrm{~min}, 30 \mathrm{~min}$ and $1 \mathrm{~h}$, but the difference reached statistical significance only in the PM group at $30 \mathrm{~min}$ (Kruskal-Wallis test, $\mathrm{p}=0.033$ with post hoc Mann-Whitney $U$ tests having $p$ values of 0.018 and 0.038 for comparisons versus

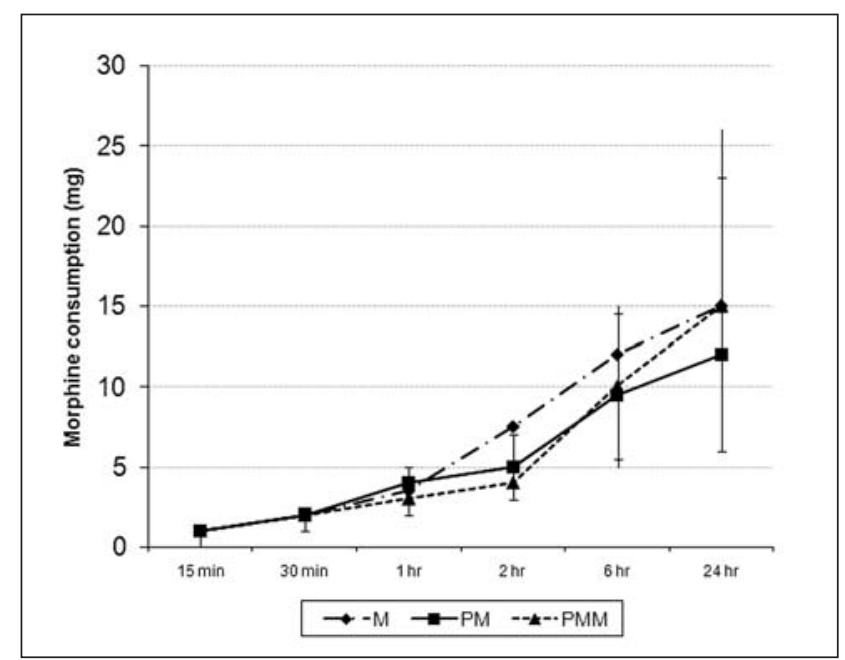

Figure 1: Morphine consumption (mg) at $15 \mathrm{~min}, 30 \mathrm{~min}, 1 \mathrm{~h}, 2$ $h, 6 h$ and $24 h$ hour of the groups. Results are expressed as mean $\pm S D$.

Groups C and P, respectively, Figure 1). The scores were similar at observations beyond $1 \mathrm{~h}$, i.e. at $2 \mathrm{~h}, 6$ $\mathrm{h}$ and $24 \mathrm{~h}$ (Table II). Median NRS scores at $2 \mathrm{~h}$ were $1(0-3)$ in all groups indicating mild pain.

In Group PM, cumulative morphine use in two patients at $6 \mathrm{~h}$ was $36 \mathrm{mg}$ and $23 \mathrm{mg}$, causing an increase in $24 \mathrm{~h}$ morphine consumption (Figure 2). Total morphine use at $24 \mathrm{~h}$ was $23.6 \pm 19.3 \mathrm{mg}$, $15.6 \pm 11.7 \mathrm{mg}$ and $18 \pm 12.8 \mathrm{mg}$ in Groups C, P and PM respectively (not significant, Figure 1)

Patient satisfaction scores were significantly higher at $15 \mathrm{~min}, 30 \mathrm{~min}, 1 \mathrm{~h}$ and $2 \mathrm{~h}$ (Kruskal-Wallis test, $\mathrm{p}=0.005,0.002,0.003$ and 0.042 , respectively) in Group PM when compared with Groups P (MannWhitney $U$ test, $\mathrm{p}=0.003,0.001,0.003$ and 0.021 , respectively) and $\mathrm{C}$ (Mann-Whitney $\mathrm{U}$ test, $\mathrm{p}=0.009$, $0.009,0.004$ and 0.042 , respectively) (Table III). Median patient satisfaction scores at 30th min were

Table I: Patients Characteristics and Duration of Surgery and Anesthesia and Total Peroperative Fentanyl Dose.

\begin{tabular}{|l|c|c|c|c|}
\hline & Placebo Group & Paracetamol Group & Paracetamol-Metamizole Group & P \\
\hline Age $(\mathrm{yr})$ & $46.8 \pm 12.7$ & $48.8 \pm 9.6$ & $48.7 \pm 10.5$ & NS \\
\hline Weight $(\mathrm{kg})$ & $77.2 \pm 18.1$ & $76.4 \pm 14.5$ & $77.1 \pm 14.2$ & NS \\
\hline Gender $(\mathrm{M} / \mathrm{F})$ & $12 / 8$ & $7 / 13$ & $10 / 13$ & NS \\
\hline Duration of surgery $(\mathrm{min})$ & $132.5 \pm 38$ & $131.3 \pm 39.1$ & $129.1 \pm 41.7$ & NS \\
\hline Duration of anesthesia $(\mathrm{min})$ & $142.5 \pm 29$ & $140 \pm 32.3$ & $143 \pm 27.3$ & NS \\
\hline Total peroperative fentanyl use $(\mu \mathrm{g})$ & $91 \pm 32.6$ & $77 \pm 15.6$ & $84 \pm 20$ & NS \\
\hline
\end{tabular}

Results were given as mean \pm SD or numbers of patients. NS: non significant, $\mathbf{P}>0.05$ 
Table II: Pain Assessment at $15 \mathrm{~min}, 30 \mathrm{~min}, 1 \mathrm{~h}, 2 \mathrm{~h}, 6 \mathrm{~h}$ and $24 \mathrm{~h}$ hour by Numerical Rating Scale (NRS, 0: no pain, 1: light pain, 2: moderate pain, 3: severe pain)

\begin{tabular}{|c|c|c|c|}
\hline Numerical Rating Scale (NRS) & Placebo Group & Paracetamol Group & Paracetamol-Metamizole Group \\
\hline NRS 15th min & $2 \pm 0.5$ & $2 \pm 0.5$ & $1 \pm 1^{*}$ \\
\hline NRS 30th min & $2 \pm 0.5$ & $2 \pm 1$ & $1 \pm 1$ \\
\hline NRS 1st hour & $2 \pm 0$ & $1 \pm 0$ & $1 \pm 0$ \\
\hline NRS 2nd hour & $1 \pm 0$ & $1 \pm 0.5$ & $0 \pm 0$ \\
\hline NRS 6th hour & $1 \pm 1$ & $1 \pm 0$ & $1 \pm 0$ \\
\hline NRS 24th hour & $1 \pm 0$ & & $2 \pm 0$ \\
\hline
\end{tabular}

Results were given as median values $\pm S D\left({ }^{*} p=0.033\right.$, Paracetamol-Metamizole versus placebo and paracetamol groups)

Table III: Patient Satisfaction Scores at 15 th, 30 th Minutes, 1st, 2nd, 6th and 24 th Hours.

\begin{tabular}{|c|c|c|c|}
\hline Patient Satisfaction (PS) & Placebo Group & Paracetamol Group & Paracetamol-Metamizole Group \\
\hline PS 15th min & $1 \pm 1$ & $1 \pm 1$ & $2 \pm 0^{*}$ \\
\hline PS 30th min & $1.5 \pm 1$ & $1 \pm 0$ & $3 \pm 1^{*}$ \\
\hline PS 1st h & $2 \pm 1$ & $2 \pm 0$ & $3 \pm 0^{*}$ \\
\hline PS 2nd h & $2 \pm 0.5$ & $2 \pm 0.5$ & $3 \pm 0$ \\
\hline PS 6th h & $3 \pm 1$ & $2.5 \pm 0.5$ & $3 \pm 0$ \\
\hline PS 24th h & $3 \pm 0$ & $3 \pm 0$ & \\
\hline
\end{tabular}

Results were expressed as median $\pm S D\left({ }^{*} p=0.005,0.002,0.003,0.042\right.$ at $15 \mathrm{~min}, 30 \mathrm{~min}, 1 \mathrm{~h}$ and $2 \mathrm{~h}$, respectively, Paracetamol-metamizole versus placebo and paracetamol groups).

\section{$1.5(0-3), 1(0-3), 2$ (1-3) in Groups C, P, PM} respectively and increased to 3 at $24 \mathrm{~h}$ in all groups.

Morphine demand in Group C was higher than in the other groups at all evaluation times with no statistical significance (Figure 2). In Group C, one patient's morphine demand was 941 and two patients' demand was 398, causing an extreme increase in the total number of demands.

There were no statistically significant differences in the incidence of nausea, vomiting, shivering, or urinary retention between the groups (Table IV).

\section{DISCUSSION}

This study showed that pain control was similar with the combination of iv paracetamol and i.v. morphine PCA compared to i.v. morphine PCA alone, but addition of metamizole provided better the early pain scores in the first postoperative two hours and increased patient satisfaction. In the early postoperative period, combination of metamizole and paracetamol with morphine PCA provided better pain control and better patient satisfaction.

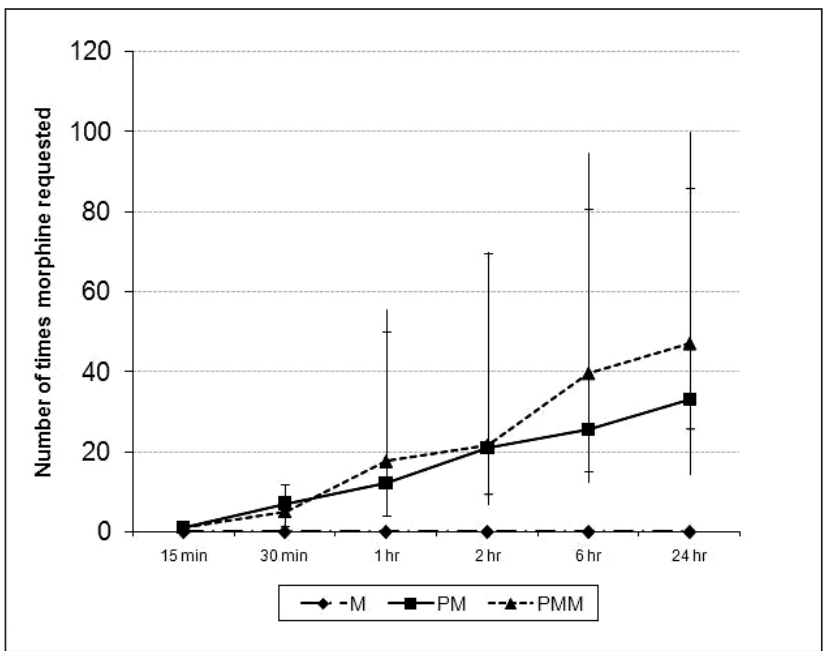

Figure 2: Morphine request (number) at $15 \mathrm{~min}, 30 \mathrm{~min}, 1 \mathrm{~h}, 2$ $h, 6 h$ and $24 h$ of the groups. Results are expressed as mean \pm SD.

NSAIDs and paracetamol have been widely used for multimodal analgesia in the postoperative period $(4,19)$. NSAIDs show their effects by inhibiting peripheral cyclooxygenase (COX). The COX enzyme has COX-1 and COX-2 subtypes. NSAIDs reduce 
Table IV: The Frequency of the Side Effects.

\begin{tabular}{|l|c|c|c|c|}
\hline & Placebo Group & Paracetamol Group & Paracetamol-Metamizole Group & P \\
\hline Nausea & $3(15 \%)$ & $5(25 \%)$ & $3(13 \%)$ & NS \\
\hline Vomiting & $3(15 \%)$ & $2(10 \%)$ & $2(8.7 \%)$ & NS \\
\hline Shivering & $0(0 \%)$ & $1(5 \%)$ & $1(4.3 \%)$ & NS \\
\hline Urinary retention & $0(0 \%)$ & $1(5 \%)$ & $2(8.7 \%)$ & NS \\
\hline
\end{tabular}

Results were given as number of patients (\%). NS: non significant $P>0.05$

prostaglandin synthesis in peripheral tissues by inhibition of the COX enzyme in the arachidonic acid metabolism $(8,19)$. Metamizole is a nonselective COX-2 inhibitor with good tolerability. COX-2 inhibitors are thought to have a lower risk/benefit ratio than traditional NSAIDs (8). In recent studies, COX-3 has been described as a variant of COX-1, which has a role in the paracetamol mechanism $(20,23)$. The combination of paracetamol with diclofenac, ketoprofen, ketorolac, suprofen and tenoxicam provided more effective analgesia than paracetamol alone $(7,12,15)$.

Paracetamol is a relatively safe nonopioid analgesic despite hepatic cell injury following highdose administration (22). Paracetamol interacts with the serotonergic system and is a centrally acting inhibitor of COX. It may be used alone or in combined analgesic regimens for the treatment of mild and moderate postoperative pain $(4,11)$. Oral, rectal and in i.v. forms of paracetamol have been available. In this study, the combination of paracetamol with metamizole and morphine PCA was investigated. Single-dose metamizole at the end of the operation along with paracetamol and morphine PCA provided better pain control. Repeated doses of metamizole would possibly provide prolonged pain control.

Metamizole is a pyrazoline-derived non-opiate analgesic drug with antipyretic and spasmolytic features. It is a widely used injectable nonopioid analgesic for postoperative pain therapy in several European countries with a low incidence of adverse reactions, but a risk of agranulocytosis. The incidence of this side effect is a matter of debate (5) and may be dependent on genetic factors, and the real incidence of agranuloscytosis due to metamizole is not known (8). Metamizole is not approved for pain therapy in the United States and Scandinavian countries. Agranulocytosis was not observed in our study group or during daily routine practice. It is widely used in our hospital with no known agranulocytosis effect. Metamizole has limited contraindications that are mostly related to the gastro-intestinal tract as common to all NSAIDs $(2,12)$. Metamizole's analgesic effect starts almost immediately after its i.v. administration and reaches its peak in 20 to 45 minutes. Methyl-aminoantipyrine and aminoantipyrine are its active metabolites. The half-life of methyl-aminoantipyrines is about 2.7 hours. Postoperative analgesia for two hours was improved with metamizole in our study, and this two-hour period is consistent with its half-life.

The effect of i.v. paracetamol on postoperative analgesia is a questionable. Sinatra et al. (21) found that visual analogue scale (VAS) score and morphine consumption were decreased, while side effects were not changed in the postoperative 24 hours following $1 \mathrm{~g}$ i.v. paracetamol and $2 \mathrm{~g}$ i.v. proparacetamol in patients undergoing major orthopedic surgery. Hernandez-Palazon et al.(10) gave $2 \mathrm{~g}$ proparacetamol per 6 hours for 3 days following spinal fusion surgery, and found that morphine consumption and pain score were significantly decreased. Many studies have found that addition of paracetamol to morphine did not decrease the pain score or morphine consumption $(4,8,18)$. The effect of non-opioid analgesics is dependent on the type of surgery performed. After retinal surgery, the analgesic potency of paracetamol is comparable to that of metamizole (13), whereas after lumbar microdiscectomy, the analgesic potency of paracetamol was inferior to metamizole (8). In contrast with the mentioned study, we added metamizole to paracetamol and found a more pronounced pain relief after lumbar discectomy. We found no difference between placebo and paracetamol groups in respect to postoperative pain 
treatment. This result was similar to that of Grungmann et al (8). It was expected that total morphine consumption would be lowest in Group PM as NRS of scores of pain were better in the early postoperative period. Although not significant, Group PM's morphine use was higher than expected. This is because two patients in Group PM used $36 \mathrm{mg}$ and $23 \mathrm{mg}$ morphine at $6 \mathrm{~h}$ (cumulative dose) hour causing an increase in total $24 \mathrm{~h}$ morphine use.

The PCA device lock-out period was $10 \mathrm{~min}$ and a $4 \mathrm{~h}$ limit was set to $20 \mathrm{mg}$ ( $1 \mathrm{~h}$ morphine limit $5 \mathrm{mg}$ and $24 \mathrm{~h}$ limit $120 \mathrm{mg}$ ). No patient in the study used $120 \mathrm{mg}$ morphine in the $24 \mathrm{~h}$ period in any group. The maximum doses used in $24 \mathrm{~h}$ were $55 \mathrm{mg}$ in Group C (one patient), $44 \mathrm{mg}$ in Group P (one patient) and $42 \mathrm{mg}$ in Group PM (one patient).

Hernandez- Delgadillo et al (9) found that single and repeated doses of metamizole increased the duration of the antinociceptive effects of morphine and potentiated its effects. The mechanisms of the acute antinociceptive synergistic effects of metamizole and morphine are not known. Peripheral activation of the arginine-nitric oxidecyclic guanosine monophosphate pathway may play a role in the antinociceptive synergistic effects of morphine and metamizole (1). In our study, metamizole was administered once at the end of the operation. Although total morphine consumption in 24 hours was the same in all groups, early pain control was better in the PM group, and this may be due in part to the synergistic effect of metamizole and morphine. Further studies should be conducted to investigate the $24 \mathrm{~h}$ morphine use if metamizole is given in repeated doses to patients undergoing lumbar disc surgery. According to Montané's (17) review article on postoperative pain therapy after traumatic orthopedic surgery (TOS), evidence regarding pain therapy after TOS was insufficient to identify the best method. It was mentioned that single-dose regimens of drugs were mostly studied, as in our study. This was the usual practice in our hospital, while prolonged postoperative pain therapy was usually under the purview of the neurosurgical department. Thus, the results of the study might be more easily applicable to routine clinical practice. The safety, route of administration, and length of action of the drug should be taken into consideration for the best treatment option.
The addition of paracetamol to morphine was previously shown to have no beneficial effect in decreasing morphine consumption, and this was also supported by our results $(4,8,18)$. Additionally, this study showed that addition of metamizole at the end of the surgery to the combination of paracetamol-i.v. morphine PCA was useful in reducing pain scores in the early postoperative period while increasing patient satisfaction.

\section{REFERENCES}

1. Aguirre-Banuelos P, Granados-Soto V: Evidence for a peripheral mechanism of action for the potentiation of the antinociceptive effect of morphine by dipyrone. J Pharmacol Toxicol Methods 42: 79-85, 1999

2. Andrade SE, Martinez C, Walker AM: Comparative safety evaluation of non-narcotic analgesics. J Clin Epidemiol 51: 1357-1365, 1998

3. Beck DH, Schenk MR, Hagemann K, Doepfmer UR, Kox WJ: The pharmacokinetics and analgesic efficacy of larger dose rectal acetaminophen $(40 \mathrm{mg} / \mathrm{kg})$ in adults: A double-blinded, randomized study. Anesth Analg 90: 431-436, 2000

4. Cakan T, Inan N, Culhaoglu S, Bakkal K, Basar H: Intravenous Paracetamol improves the quality of postoperative analgesia but does not decrease narcotic requirements. J Neurosurg Anesthesiol 20: 169-173, 2008

5. Edwards JE, McQuay HJ: Dipyrone and agranulositosis: What is the risk? Lancet 360: 1438, 2002

6. Fayaz MK, Abel RJ, Pugh SC, Hall JE, Djaiani G, Mecklenburgh JS: Opioid-sparing effects of diclofenac and paracetamol lead to improved outcomes after cardiac Surgery. J of Cardiothorac Vasc Anesth 18: 742-747, 2004

7. Fletcher D, Negre I, Barbin C, Francois A, Carreres C, Falgueirettes C, Barboteu A, Samii K: Postoperative analgesia with iv propacetamol and ketoprofen combination after disc surgery. Can J Anaesth 44: 479-485, 1997

8. Grundmann U, Wörnle C, Biedler A, Kreuer S, Wrobel M, Wilhelm W: The efficacy of the non-opioid analgesics paracoxib, paracetamol and metamizol for postoperative pain relief after lumbar microdiscectomy. Anesth Analg 103: 217222, 2006

9. Hernandez-Delgadillo GP, Ventura Martínez R, Díaz Reval MI, Domínguez Ramírez AM, López-Muñoz FJ: Metamizol potentiates morphine antinociception but not constipation after chronic treatment. Eur J Pharmacol 441: 177-183, 2002

10. Hernandez-Palazon J, Tortosa JA, Martinez-Lage JF, PerezFlores D: Intravenous administration of propacetamol reduces morphine consumption after spinal fusion surgery. Anesth Analg 92: 1473-1476, 2001

11. Hynes D, McCarroll M, Hiesse-Provost O: Analgesic efficacy of paranteral paracetamol (propacetamol) and diclofenac in post-operative orthopedic pain. Acta Anaesthesiol Scand 50: 374-381, 2006

12. Lancker PV, Vandekerckhove B, Cooman F: The analgesic effect of preoperative administration of propacetamol, tenoxicam or a mixture of both in arthroscopic, outpatient knee surgery. Acta Anaesthesiol Belg 50: 65-69, 1999 
13. Landwehr S, Kiencke P, Giesecke T, Eggert D, Thumann G, Kampe S: A comparison between IV paracetamol and IV metamizol for postoperative analgesia after retinal surgery. Curr Med Res Opin 21: 1569-1575, 2005

14. LŞpez Muñoz FJ, Godínez- Chaparro B, Huerta-Cruz JC, Guevara-LŞpez U, Domínguez-Ramírez AM, Cortés-Arrovo AR: The antinociceptive efficacy of morphine, metamizol, or their combination in an experimental rat model with different levels of inflammatory pain. Pharmacol Biochem Behav 91: 196-201, 2008

15. Mather SJ, Peutrell JM: Postoperative morphine requirements, nause and vomiting following anaesthesia for tonsillectomy. Comparison of intravenous morphine and non-opioid analgesic techniques. Paediatr Anaesth 5: 185-188, 1995

16. Matthews RW, Scully CM, Levers BGH: The efficacy of diclofenac sodium (voltarol) with and without paracetamol in the control of post-surgical dental pain. Br Dent J 157: 357-359, 1984

17. Montané E, Vallano A, Aguilera C, Vidal X, Laporte JR: Analgesics for pain after traumatic or orthopedic surgery: What is the evidence - a systematic review. Eur J Clin Pharmacol 62: 971-988, 2006

18. Ohnesorge H, Bein B, Hanss R, Francksen H, Mayer L, Schlz J, Tonner PH: Paracetamol versus metamizole in the treatment of postoperative pain after breast surgery: A randomized, controlled trial. Eur J Anaesthesiol 26: 648-653, 2009
19. Romsing J, Moiniche S, and Dahl JB: Rectal and parenteral paracetamol, and paracetamol in combination with NSAIDs, for postoperative analgesia. Br J Anaesth 88: 215-226, 2002

20. Sandrini M, Vitale G, Ruggieri V, Pini LA: Effect of acute and repeated administration of paracetamol on opioidergic and serotonergic systems in rats. Inflamm Res 56; 139-142, 2007

21. Sinatra RS, Jahr JS, Reynolds LW, Viscusi ER, Groudine SB, Payen-Champenois C: Efficacy and safety of single and repeated administration of $1 \mathrm{~g}$ intravenous acetaminophen injection (paracetamol) for pain management after major orthopedic surgery. Anesthesiology 102: 822-831, 2005

22. White PF: The changing role of nonopioid analgesic techniques in the management of postoperative pain. Anesth Analg 101: S5-S22, 2005

23. Wilson SG, Bryant CD, Lariviere WR, Olsen MS, Giles ME, Chesler EJ, Mogil JS: The Heritability of antinociception II; pharmacogenetic mediation of three over-the-counter analgesics in mice. J Pharmacol Exp Ther 304: 547-559, 2003 